\title{
Combined Sewer Overflow pretreatment with chemical coagulation and a particle settler for improved peracetic acid disinfection
}

\author{
Chhetri, Ravi Kumar; Bonnerup, Arne; Andersen, Henrik Rasmus
}

Published in:

Journal of Industrial and Engineering Chemistry

Link to article, DOI:

10.1016/j.jiec.2016.03.049

Publication date:

2016

Document Version

Peer reviewed version

Link back to DTU Orbit

Citation (APA):

Chhetri, R. K., Bonnerup, A., \& Andersen, H. R. (2016). Combined Sewer Overflow pretreatment with chemical coagulation and a particle settler for improved peracetic acid disinfection. Journal of Industrial and Engineering Chemistry, 37, 372-379. https://doi.org/10.1016/j.jiec.2016.03.049

\section{General rights}

Copyright and moral rights for the publications made accessible in the public portal are retained by the authors and/or other copyright owners and it is a condition of accessing publications that users recognise and abide by the legal requirements associated with these rights.

- Users may download and print one copy of any publication from the public portal for the purpose of private study or research.

- You may not further distribute the material or use it for any profit-making activity or commercial gain

- You may freely distribute the URL identifying the publication in the public portal 
This is a post print of the article accepted for publication on March 30, 2016 in the "Journal of Industrial and Engineering Chemistry".

DOI information: $10.1016 / \mathrm{j}$. jiec. 2016.03.049

\section{Combined Sewer Overflow pretreatment with chemical coagulation and a particle settler for improved peracetic acid disinfection}

Ravi Kumar Chhetri ${ }^{\mathrm{a}}$, Arne Bonnerup ${ }^{\mathrm{b}}$ and Henrik Rasmus Andersen ${ }^{\mathrm{a}}$

${ }^{a}$ Department of Environmental Engineering, Technical University of Denmark, Bygningstorvet, Building 115, 2800 Kgs. Lyngby, Denmark.

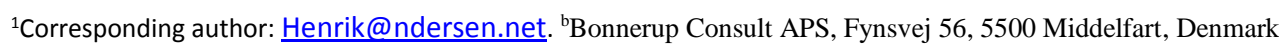

\section{Highlights}

- CSO disinfection was investigated by coagulation, settling and peracetic acid dosage

- Particle separation improved peracetic acid exposure and disinfection efficiency

- Applying PAX-XL 100 before the separator further increased disinfection efficiency

- Above 1-log Enterococcus removal in untreated CSO requires $10 \mathrm{mg} / \mathrm{L}$ peracetic acid

- 1-log Enterococcus removal improved with pretreatment to $2 \mathrm{ppm}$ peracetic acid
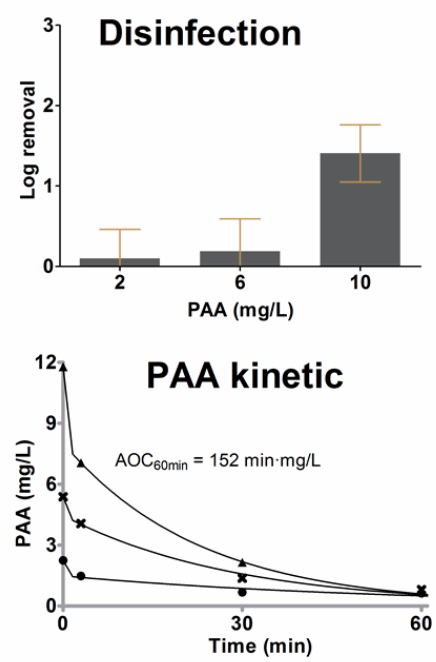

Hydroseparator

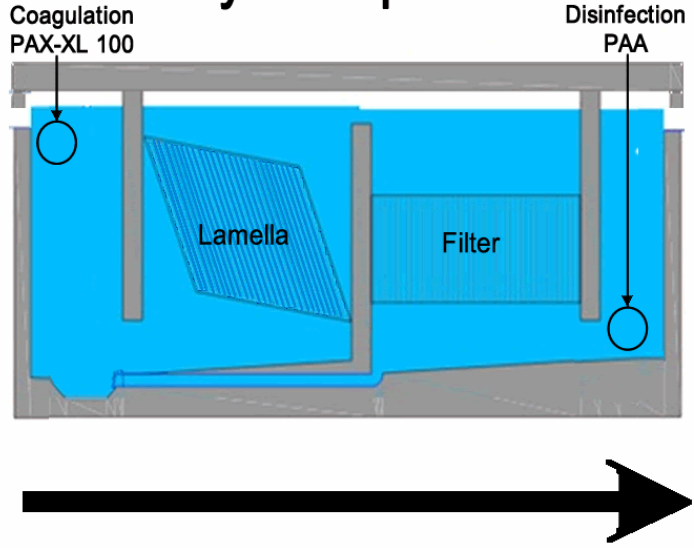

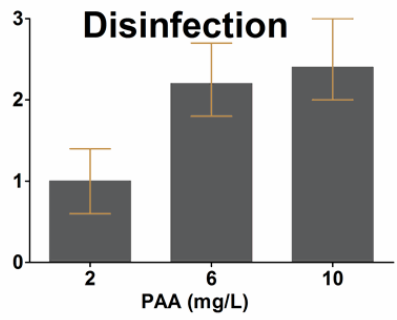

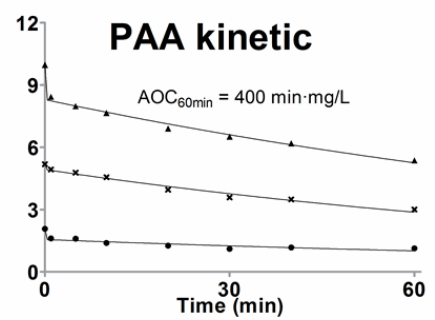


Abstract Full scale disinfection by peracetic acid (PAA) was achieved on combined sewer overflow (CSO) water, which was pre-treated physically by a fast settling-filtration unit. Disinfection of untreated CSO water using PAA was compared to treatment using a particle separator (HydroSeparator ${ }^{\circledR}$ ) and additional coagulation with poly-aluminum-chloride. Disinfection for Enterococcus increased with the applied dose of PAA and additional improvement was achieved when it was preceded by chemical coagulation with $5 \mathrm{mg} \cdot \mathrm{L}^{-1}$ poly-aluminum-chloride. When Enterococcus was reduced by treatment in the HydroSeparator, followed by PAA treatment during a CSO event, the treatment was sufficient to maintain microbial quality in the recipient water. 


\section{Introduction}

Many old cities are drained by combined sewer systems, in which wastewater is mixed with rain water and transported to a wastewater treatment plant for processing. When significant rainfall events occur, design capacity of combined sewer systems can be exceeded, resulting in the discharge of untreated combined sewer overflow $(\mathrm{CSO})^{1}$ to nearby surface waters through prepared emergency structures. Discharge of untreated CSO gives rise to acute impacts on the quality of receiving waterbodies, as it contains a variable mixture of rain water, raw sewage, watershed run-off pollutants, variable pathogenic organisms, viruses, cysts, suspended solids, chemicals, and floatable materials [1]. In recent years, the impact of CSOs on water bodies used for recreational purposes has become an issue of concern in Europe. The European Union (EU) has strove to regulate bathing water quality by issuing a series of bathing water directives; one of which stipulates that in terms of good microbial content, the density of $E$. coli should not exceed 500 MPN and Enterococcus 200 MPN per $100 \mathrm{~mL}$ of water intended for recreational purposes, based upon 95 percentile evaluation. For bathing water of sufficient quality, the number of indicator organisms should not exceed 500 E. coli per $100 \mathrm{~mL}$ and 185 Enterococcus per $100 \mathrm{~mL}$ water intended for recreational purposes, based upon 90 percentile evaluation [2].

Safe bathing water quality, in terms of microbial load, can be maintained by disinfection of inflowing CSO water. According to Tchobanoglous et al. [3], an ideal disinfectant should guarantee maximum efficiency in pathogenic microorganism removal, without generating toxic and undesirable by-products. Furthermore, the disinfection process should be inexpensive and technologically compatible with other parts of the water treatment [3]. Various well known disinfectants are currently used in the water industry, such as hypochlorite

\footnotetext{
${ }^{1}$ Abbreviations applied in this manuscript:

ABTS $=2,2$ "-azino-bis [3-ethylbenzothiazoline-6-sulfonic acid] diammonium salt

$A U C x=$ Area under the curve of disinfection concentration until $x$ min of disinfection.

COD = Chemical oxygen demand

CSO = Combined sewer overflow.

MPN = Most probable number.

PAA = Peracetic acid.

$\mathrm{PAX}=$ Polyaluminium chloride

SS = Suspended solids.
} 
and chlorine dioxide [4], which could be used to reduce contamination by microorganisms from CSO events. However, unfortunately the by-products of these compounds are of environmental concern [5-9]. Alternatively, the organic peroxide peracetic acid (PAA) is a strong disinfectant with a wide spectrum of antimicrobial activity, which was introduced to wastewater treatment approximately 30 years ago [10-15]. Commercial PAA is available as an acidic quaternary equilibrium mixture of PAA, hydrogen peroxide, acetic acid, and water:

$$
\mathrm{CH}_{3} \mathrm{COOH}+\mathrm{H}_{2} \mathrm{O}_{2} \rightleftharpoons \mathrm{CH}_{3} \mathrm{CO}_{3} \mathrm{H}+\mathrm{H}_{2} \mathrm{O}
$$

The residues after PAA use are acetic acid, hydrogen peroxide, and water. Acetic acid is further biodegraded to carbon dioxide whilst hydrogen peroxide degrades to oxygen and water; neither of which is considered toxic to aquatic life [16]. Recently, we investigated at laboratory scale the potential to employ peracetic acid and performic acids for disinfection of CSO in terms of dosage, kinetics, and residual disinfectants [17]. Additionally, we previously demonstrated for the first time, full- scale use of performic acid disinfection of CSO by using a sea outfall pipe as reaction tank [18].

The efficiency of a disinfection method can be increased if CSO water is pretreated with physical and/or chemical processes, such as chemical coagulation or filtration. The primary purpose of physical chemical treatment is to reduce suspended solids and therefore any contaminants associated with them. Among various physical chemical treatment processes in wastewater technology, employment of chemical coagulation, followed by introduction of lamella clarifiers is most common. Suspended solids and other pollutants from wastewater can be removed by chemical coagulation, followed by lamella clarification; and the process is considered an essential component of wastewater treatment [3]. Lamella clarifiers (comprised of a series of inclined-plates) were designed to remove particulates from CSO water. When CSO water flows over lamella in a clarifier, particles settle on the inclined plates accumulating in the associated collection hopper, resulting in effective removal of suspended solids. 
Chemical coagulation is the process of the formation of flocs (large particles) from finely divided and destabilized particles. Studies concerning chemical coagulation and lamella clarification of CSO have shown efficient removal of total suspended solids ( $80 \%)$, COD ( $60 \%)$, total phosphorus ( 85\%) [19-21] and heavy metals ( 75\%) [22]. A broad spectrum of pollutants from CSO water has also been treated by ballasted flocculation [23] and priority pollutants by lamella clarification [24]. Furthermore, coagulation followed by disc filtration has been used to remove polycyclic aromatic hydrocarbons associated with micro particles in storm water [25]. Finally, removal of suspended solids and E. coli from CSO water has been demonstrated by drum and disc filtration, followed by UV disinfection [26]. To our knowledge, there are no studies currently available in the literature concerning disinfection of CSO water by chemical coagulation followed by lamella clarification. The following article describes such a study.

Application of physico-chemical pretreatment of CSO effluent will likely lead to improved disinfection efficiency and alter the degradation kinetics of PAA. Clearly, it is important to quantify this process in order to operate a full scale CSO treatment facility efficiently and effectively. Thus, the aim of this study was to test a full scale PAA disinfection system for CSO in terms of its design and performance. The design of the study and system is based on our previous work in addition to chemical coagulation using real CSO water. Furthermore, this study also investigates the degradation kinetics of PAA in CSO water before and after chemical coagulation.

\section{Material and methods}

\subsection{Chemicals}

ABTS (2,2"-azino-bis [3-ethylbenzothiazoline-6-sulfonic acid] diammonium salt), sodium thiosulphate, and catalase from bovine liver (2000-5000 units/mg protein) were all purchased from Sigma-Aldrich (Brøndby, Denmark). All chemicals were of reagent grade. PAA (CAS no: $79-21-0$ ) solution containing $30-40 \% \mathrm{w} / \mathrm{w}$ of 
technical grade disinfectant was supplied by Sigma-Aldrich (Brøndby, Denmark). PAX-XL 100 solution containing $9.3 \% \mathrm{w} / \mathrm{v}$ Al with basicity $43 \pm 2 \%$ was supplied from Kemira Water Denmark (Copenhagen, Denmark).

\subsection{Chemical analysis}

Turbidity, phosphate, and suspended solids were determined according to standard methods [27] and using standard operating procedures and control methods from the general water laboratory at Department of Environmental Engineering, Technical University of Denmark. PAA concentration was analyzed using the colorimetric method described by Chhetri et al. [17] based on selective oxidation of ABTS by PAA without interference from hydrogen peroxide.

\subsection{Microbiological analysis}

Samples were processed within $2 \mathrm{~h}$ after collection. Residues of PAA were neutralized in laboratory experiments by adding $100 \mathrm{mg} \cdot \mathrm{L}^{-1}$ sodium thiosulphate, followed by $50 \mathrm{mg} \cdot \mathrm{L}^{-1}$ catalase to destroy hydrogen peroxide [28]. Enterococcus were enumerated using the Enterolert methods from IDEXX (IDEXX laboratories, Maine, United States), as described by Chhetri et al. [17].

\subsection{Site description}

The HydroSeparator ${ }^{\circledR}$ CSO system (HydroSeparator) was installed in Kærby, a small city in Middelfart, Denmark to treat CSO from the towns of Båring and Asperup following extreme weather (i.e. significant precipitation events), which usually occurs at least several times a year. During these extreme events, treatment capacity of Nørre Aaby wastewater treatment plant is exceeded and CSO is consequently discharged to a surface water body. Prior to installation of the HydroSeparator, untreated CSO has been discharged to Kærbyholm canal, which flows to Pavebækken stream, which further flows into Storeå river before finally entering the sea near the towns of Varbjerg and Bro. The HydroSeparator is a patented and specialized system designed to effectively clean CSO, minimizing the environmental impact to receiving water bodies such as rivers, harbors, beaches etc. The HydroSeparator is equipped with lamella, followed by a filter 
with sieve size of 20 microns (Figure 1). The HydroSeparator has a capacity to treat CSO water at a flow rate of $5-25 \mathrm{I} \cdot \mathrm{s}^{-1}$. The principle use of the HydroSeparator is to remove suspended solids (SS) from CSO discharge during extreme weather events, which also, in turn reduces pollutants associated with them. At the Kærby site, particles greater than $4 \mathrm{~mm}$ present in the CSO are removed by a mechanical screen prior to flow into the HydroSeparator. Retention time of CSO water in the HydroSeparator is determined based on flow rate into the system. In maximal flow, the retention time of CSO water in the HydroSeparator is 7 min, whilst during minimum flow retention time is $35 \mathrm{~min}$. To optimize removal of larger SS's during flow through the HydroSeparator, chemical coagulation was employed at the inlet. After treatment by flow-through of the HydroSeparator, CSO water is further disinfected with PAA in a reaction chamber, which then flows to a constructed wetland. In this study, any effects or processes associated with the constructed wetland following discharge of treated CSO were not investigated.

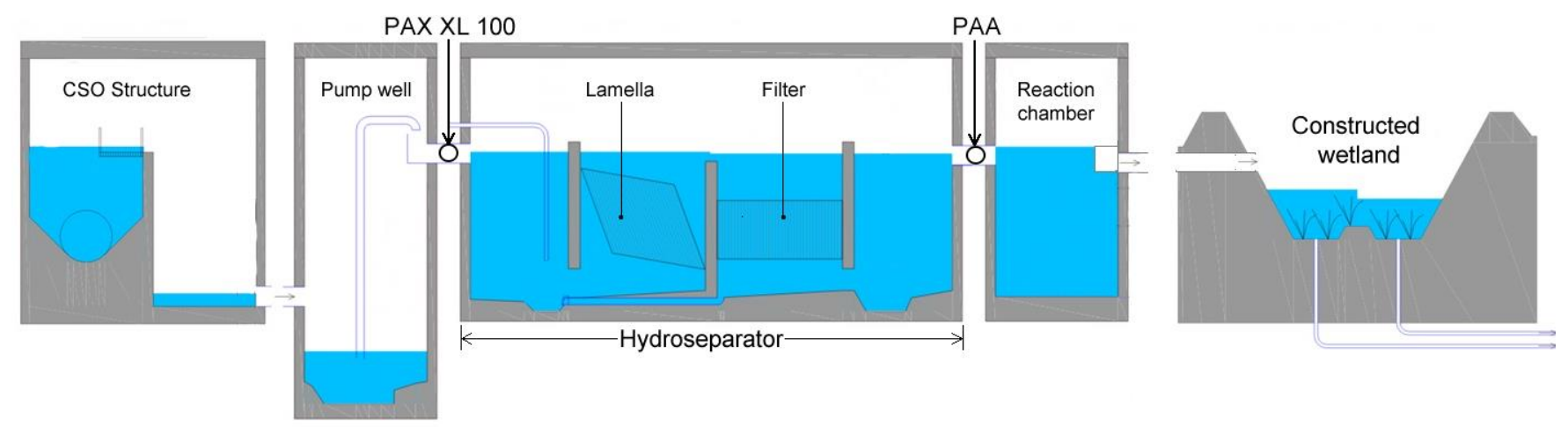

Figure 1: Schematic diagram of the Kærby plant including the CSO overflow structure with a weir, the PAX dosing point before the HydroSeparator followed by a dosing point for PAA and a reaction tank finally leading to a constructed wetland

\subsection{Experiment performed}

This study was divided into three sub-experiments: Experiment I- study of disinfection, Experiment II- study of pre-treatment with chemical coagulation and Experiment III- study of full scale disinfection after in-situ chemical coagulation. The first two experiments were performed in the laboratory to design the ideal dose of coagulant and disinfectant, whilst the final experiment was performed at field scale using the Kærby HydroSeparater system, dosing coagulant and disinfectant at full scale. 
In experiment I, four samples were collected from the HydroSeparator; one from the inlet and three from the outlet at varying flow rates. PAA was added at doses of 2,6 , and $10 \mathrm{mg} \cdot \mathrm{L}^{-1}$, with concentration profiles over time measured until $180 \mathrm{~min}$. In parallel, following 60 min of contact time, residual PAA from samples was neutralized by adding $100 \mathrm{mg} \cdot \mathrm{L}^{-1}$ sodium thiosulphate, followed by $50 \mathrm{mg} \cdot \mathrm{L}^{-1}$ catalase as described by Chhetri et al., [17] to enumerate Enterococcus. Our previous study concerning disinfection of E. coli and Enterococcus from CSO water showed that Enterococcus always required a higher dose of disinfectant and was more difficult to disinfect than E. coli $[17,18]$ thus, Enterococcus can be used exclusively for dimensioning. Therefore, only the disinfection efficiency on the removal of Enterococcus was considered in this study.

In experiment II, two samples were collected from the inlet and outlet of the HydroSeparator at varying flow rates. Next, the process of chemical coagulation for these samples was explored by employing jar tests using different concentration of PAX-XL100. Chemical coagulation was achieved by placing $1 \mathrm{~L}$ of influent sample in 6 glass jars then adding PAX-XL 100 to form aluminum doses of $2.5,3.5,5,7.5,10$ and $15 \mathrm{mg}-\mathrm{Al} \cdot \mathrm{L}^{-1}$. Samples were rapidly mixed for one minute at $120 \mathrm{rpm}$ and the speed of mixing was reduced to minimum for $7 \mathrm{~min}$. The samples were then rested for 15 min to allow settling of developed flocs. During settling, turbidity was measured after 5, 10, and 15 minutes. Phosphate was measured for each sample before chemical coagulation and after 15 minutes of settling in chemical coagulation to assess removal. Moreover, $\mathrm{pH}$ was measured from samples treated with different concentrations of PAX-XL 100 to observe the effect of coagulant on change in $\mathrm{pH}$ (see supporting information figure S1 and S2). The most effective dose observed in these jar tests (i.e. inducing the greatest levels of coagulation) was then employed during the full scale chemical coagulation experiment (experiment III).

In experiment III, a full scale assessment of the optimized treatment process was performed by applying 5 mg-Al. $\mathrm{L}^{-1} \mathrm{PAX}-\mathrm{XL} 100$ as coagulant prior to inflow to the HydroSeparator, followed by disinfection with 10 $\mathrm{mg} \cdot \mathrm{L}^{-1} \mathrm{PAA}$ at the outflow. Samples from inlet, outlet post chemical coagulation, and outlet post disinfection chamber were then taken and transported to the laboratory for analysis. In order to confirm the PAA dose delivered in the field, comparable PAA treatments were made on field collected samples after chemical 
coagulation in the laboratory. After $10 \mathrm{~min}$ and $60 \mathrm{~min}$ of contact time, an aliquot of each sample was processed for Enterococcus enumeration and in parallel concentration profiles of PAA were observed for approximately $60 \mathrm{~min}$ in the remaining sample volume. Samples attained from the outlet of the disinfection unit were separated in two $1 \mathrm{~L}$ bottles and then neutralized (in terms of residual PAA) after 10 and 60 minutes contact time by adding sodium thiosulphate and catalase as described above. Enterococcus was then enumerated upon arrival at the laboratory (maximally $4 \mathrm{~h}$ ). Another full scale experiment was performed by applying the same concentration of coagulant and disinfectant, as described above, to assess the effect of removing Enterococcus from the CSO. Samples were analyzed from the point the sewer overflow entered the treatment system to the end of the treatment after CSO event and following the flow in the branched river system into the local beach before CSO event.

\section{Results and discussion}

\subsection{Quality of CSO water}

The quality of CSO water attained from the HydroSeparator during experiments I and III is presented in Table 1.

\begin{tabular}{|c|c|c|c|c|c|c|}
\hline & \multicolumn{4}{|c|}{ Experiment I } & \multicolumn{2}{|c|}{ Experiment III } \\
\hline & \multicolumn{5}{|c|}{ HydroSeparator } & \multirow{3}{*}{$\begin{array}{l}\text { HydroSeparator } \\
6 \mathrm{l} \cdot \mathrm{s}^{-1} ; 5 \mathrm{mg}-\mathrm{Al} \cdot \mathrm{L}^{-1}\end{array}$} \\
\hline & Inlet & & & & Inlet & \\
\hline & & $25 \mathrm{I} \cdot \mathrm{s}^{-1}$ & $15 \mathrm{I} \cdot \mathrm{s}^{-1}$ & $5 \mathrm{I} \cdot \mathrm{s}^{-1}$ & & \\
\hline Turbidity (NTU) & N.A & N.A & N.A & N.A & 37.1 & 3.8 \\
\hline $\mathrm{SS}\left(\mathrm{mg} \cdot \mathrm{L}^{-1}\right)$ & 31.6 & 22.6 & 10.9 & 8.6 & N.A & N.A \\
\hline Phosphate, $\mathrm{PO}_{4}{ }^{3-}\left(\mathrm{mg} \cdot \mathrm{L}^{-1}\right)$ & 2.3 & 2.9 & 2.9 & 2.7 & 1.5 & 1.1 \\
\hline
\end{tabular}

N.A=Not analyzed

Experiment I was performed in order to optimize the inflow to the HydroSeparator with 3 different flow rates. Considering flow rates of 5,15 , and $25 \mathrm{I} \cdot \mathrm{s}^{-1}$, flow at $5 \mathrm{l} \cdot \mathrm{s}^{-1}$ appeared to most efficiently remove suspended 
solids after the HydroSeparator. Experiment III was performed using this determined optimized inflow in addition to application of the chemical coagulant optimized, as described in section 3.2. Consequently, experiment III shows $89.8 \%$ of turbidity, and $26.6 \%$ of phosphate was removed by combination of treatment by the HydroSeparator and chemical coagulation. Overall, the HydroSeparator in combination with chemical coagulation efficiently removed the turbidity and decreased phosphate, thereby minimizing the environmental impact on receiving surface water bodies following CSO discharge.

\subsection{Chemical coagulation}

Chemical coagulation is an effective method by which to improve water quality by reducing turbidity and contaminants such as phosphate. For the current study, chemical coagulation was induced in samples collected from the inlet of the HydroSeparator (by traditional jar test), the results of which are shown in Figure 2. Results show turbidity was reduced to $3 \mathrm{NTU}$ from $52 \mathrm{NTU}$ by applying $5 \mathrm{mg}-\mathrm{Al} \cdot \mathrm{L}^{-1}$ with $15 \mathrm{mins}$ of sedimentation, whilst greater than $5 \mathrm{mg}-\mathrm{Al} \cdot \mathrm{L}^{-1}$ achieved insignificant further improvements. Phosphate was reduced to $0.63 \mathrm{mg} \cdot \mathrm{L}^{-1}$ from $2.43 \mathrm{mg} \cdot \mathrm{L}^{-1}$ in samples coagulated with $5 \mathrm{mg}-\mathrm{Al} \cdot \mathrm{L}^{-1}$. In experiment III, full scale chemical coagulation was studied in the HydroSeparator based on the experimental results from experiment II. Turbidity removal was $89.8 \%$, whereas phosphate removal was $26.6 \%$ (Table 1 ). 

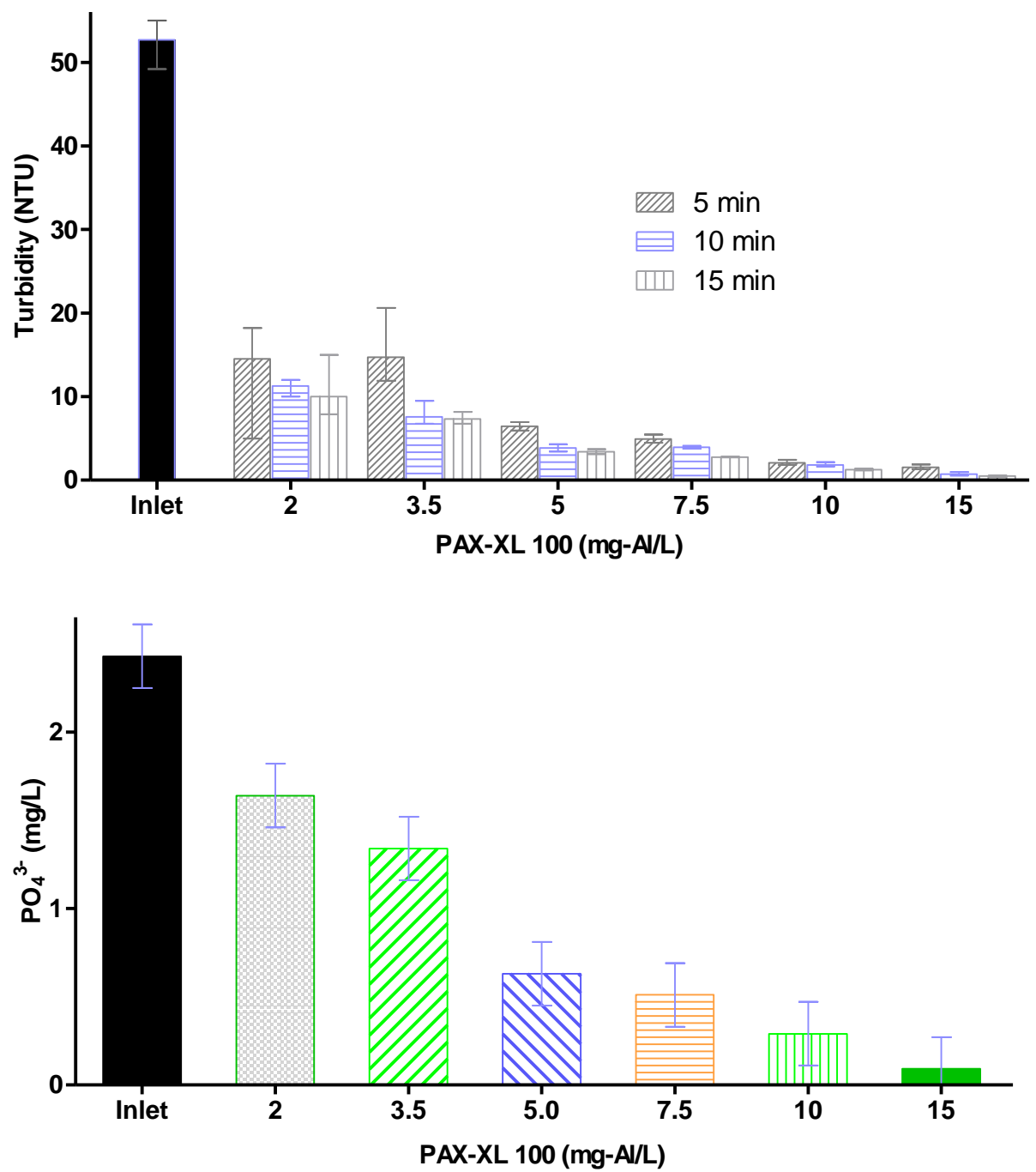

Figure 2: Effect of coagulant (PAX XL100) in Jar test on turbidity and phosphate concentrations of CSO water taken from the inlet of the HydroSeparator. Phosphate removal from coagulated samples were measured after 15 min of sedimentation time in Jar test. T-bars indicate range of measured values for the graph with turbidity and $95 \%$ confidence interval for graph with phosphate

\subsection{Peracetic acid concentration profiles}

Concentration profiles of PAA in CSO samples are presented in Figure 3. During experiment I, four samples, one at the HydroSeparator inlet and three at the outlet were collected at different flow rates and disinfected with 2, 6 and $10 \mathrm{mg} \cdot \mathrm{L}^{-1} \mathrm{PAA}$. An apparent high initial consumption of PAA was observed in all samples (Figure 3) with initial consumption of PAA increasing with increased nominal PAA dose. Thus, the initial consumption of PAA was $2.7 \mathrm{mg} \cdot \mathrm{L}^{-1}$ on average when $10 \mathrm{mg} \cdot \mathrm{L}^{-1}$ PAA was used in experiment $\mathrm{l}$; whereas the initial 
consumption was observed as $1.67 \mathrm{mg}^{-\mathrm{L}^{-1}}$ by applying the same concentration of PAA to disinfect the CSO water pretreated with the HydroSeparator and chemical coagulation in experiment III. First order degradation kinetics did not fit the observed data, due to a considerable initial consumption of oxidants (see supporting information figure S3 and Table S1). To address the initial consumption of PAA, Antonelli et al. [10] and Falsanisi et al. [11] applied a modified first order kinetics expression to model the concentration profile of PAA in wastewater effluents, including a parameter describing initial oxidant consumption as described by Haas and Finch, [29]:

$$
C_{t}=\left(C_{o}-C_{\text {Initial }}\right) * e^{-k t}
$$

In eq. $2 C_{t}$ is the residual disinfectant concentration at time $t, C_{o}$ is the applied disinfectant dose, $C_{\text {Initial }}$ is the initial oxidant consumption, $k$ is the rate constant, and $t$ is time. Fitted curves generated using this modified first order expression are shown in Figure 3 with derived parameters presented in Table 2.

An initial loss in concentration was not observed when PAA was applied to CSO water attained from another site by Chhetri et al., [17] nor in primary treated wastewater [28]. Hey et al., [30] also observed minimal initial consumption when PAA was used to remove pharmaceutical compounds from tertiary treated wastewater. Furthermore, degradation of PAA was slower in the CSO water from the alternate site, the primary treated wastewater, and in the tertiary treated wastewater [30].

Unfortunately we cannot at present time offer any explanation for the high initial consumption and faster degradation of PAA in the CSO water attained in the current study, compared to water investigated from other sites. We speculate however, that there may be inflow of surface water into the CSO system somewhere in the catchment. The algae in the surface water might contain catalase-like enzymes that might cause faster degradation of PAA. More rapid degradation of PAA in surface waters than in the CSO and WWTP effluents has previously been reported, such as in our previous kinetics focused study [31]. 

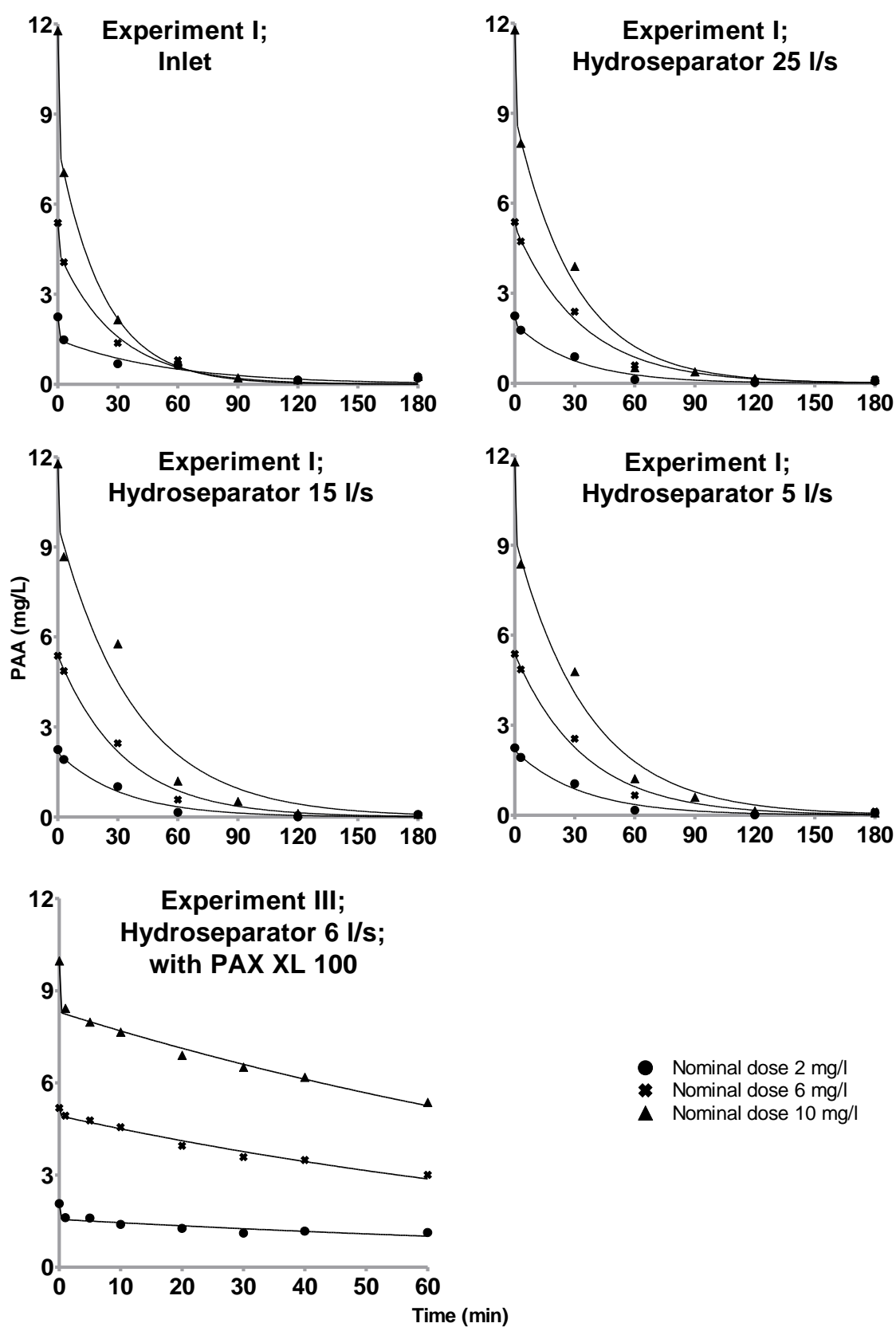

- Nominal dose $2 \mathrm{mg} / \mathrm{l}$

Nominal dose $6 \mathrm{mg} / \mathrm{l}$

A Nominal dose $10 \mathrm{mg} / \mathrm{l}$

Figure 3: Concentration profile of different levels of PAA added to CSO water collected from the HydroSeparator with different

flow and use of coagulant. Curve was fitted using modified first order degradation kinetics using equation 2

The area under the curve (AUC) of the PAA concentration profile with time was determined for 60 mins of reaction for experiment I and for both $10 \mathrm{~min}$ and $60 \mathrm{~min}$ for experiment III. The AUC data (table 2) shows clearly that the degradation kinetics of PAA was affected by HydroSeparator treatment and pretreatment 
with chemical coagulation leads to even slower degradation. This can be explained by the increased removal of particles and dissolved matter that would otherwise react with PAA.

Table 2: Fitted parameters of concentration curves and area under the curve for concentration profiles shown in Figure 3

\begin{tabular}{|c|c|c|c|c|c|c|}
\hline Sample & $\begin{array}{c}\text { Nominal dose } \\
\left(\mathrm{mg} \cdot \mathrm{L}^{-1}\right)\end{array}$ & $\begin{array}{c}C_{\text {Initial }} \\
\left(\mathrm{mg} \cdot \mathrm{L}^{-1}\right)\end{array}$ & $\begin{array}{c}k \\
\left(\mathrm{~min}^{-1}\right)\end{array}$ & $\mathbf{R}^{2}$ & $\begin{array}{c}\mathrm{AUC}_{60 \mathrm{~min}} \\
\left(\mathrm{mg} \cdot \mathrm{L}^{-1} \cdot \mathrm{min}\right)\end{array}$ & $\begin{array}{c}\text { AUC }_{10 \min } \\
\left(\mathrm{mg} \cdot \mathrm{L}^{-1} \cdot \mathrm{min}\right)\end{array}$ \\
\hline \multirow{3}{*}{ Inlet } & 2 & 0.76 & $1.8 \cdot 10^{-2}$ & 0.98 & 54 & N.A \\
\hline & 6 & 0.92 & $3.5 \cdot 10^{-2}$ & 0.99 & 120 & N.A \\
\hline & 10 & 3.75 & $4.4 \cdot 10^{-2}$ & 0.99 & 152 & N.A \\
\hline HydroSeparator & 2 & 0.26 & $3.2 \cdot 10^{-2}$ & 0.98 & 57 & N.A \\
\hline \multirow{2}{*}{$25 \mathrm{~L} \cdot \mathrm{s}^{-1}$} & 6 & 0.14 & $3.0 \cdot 10^{-2}$ & 0.99 & 156 & N.A \\
\hline & 10 & 2.80 & $3.3 \cdot 10^{-2}$ & 0.99 & 257 & N.A \\
\hline HydroSeparator & 2 & 0.11 & $3.1 \cdot 10^{-2}$ & 0.99 & 63 & N.A \\
\hline \multirow{2}{*}{$15 \mathrm{~L} \cdot \mathrm{s}^{-1}$} & 6 & $\sim 0$ & $3.0 \cdot 10^{-2}$ & 0.99 & 160 & N.A \\
\hline & 10 & 1.99 & $2.6 \cdot 10^{-2}$ & 0.98 & 330 & N.A \\
\hline HydroSeparator & 2 & 0.09 & $3.0 \cdot 10^{-2}$ & 0.98 & 65 & N.A \\
\hline \multirow{2}{*}{$5 \mathrm{~L} \cdot \mathrm{s}^{-1}$} & 6 & $\sim 0$ & $2.9 \cdot 10^{-2}$ & 0.99 & 164 & N.A \\
\hline & 10 & 2.47 & $2.8 \cdot 10^{-2}$ & 0.99 & 298 & N.A \\
\hline \multirow{3}{*}{$\begin{array}{l}\text { HydroSeparator } \\
6 \mathrm{~L} \cdot \mathrm{s}^{-1} ; 5 \mathrm{mg}-\mathrm{Al} \cdot \mathrm{L}^{-1}\end{array}$} & 2 & 0.51 & $0.7 \cdot 10^{-2}$ & 0.92 & 75 & 16 \\
\hline & 6 & 0.26 & $0.9 \cdot 10^{-2}$ & 0.98 & 228 & 48 \\
\hline & 10 & 1.67 & $0.7 \cdot 10^{-2}$ & 0.99 & 400 & 81 \\
\hline
\end{tabular}

N.A=Not analyzed

\subsection{Disinfection efficacy}

Disinfection efficiency was derived by comparing concentration of Enterococcus measured in the samples before and after treatment with PAA. Results are presented in Figure 4. 


\section{Experiment I}

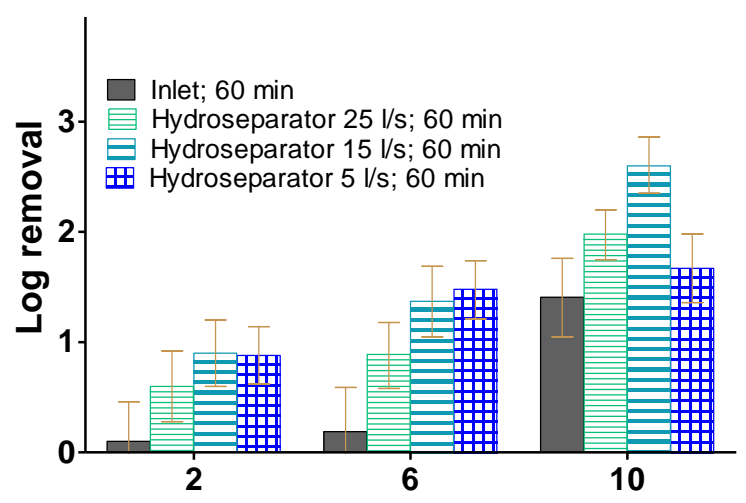

\section{Experiment III}

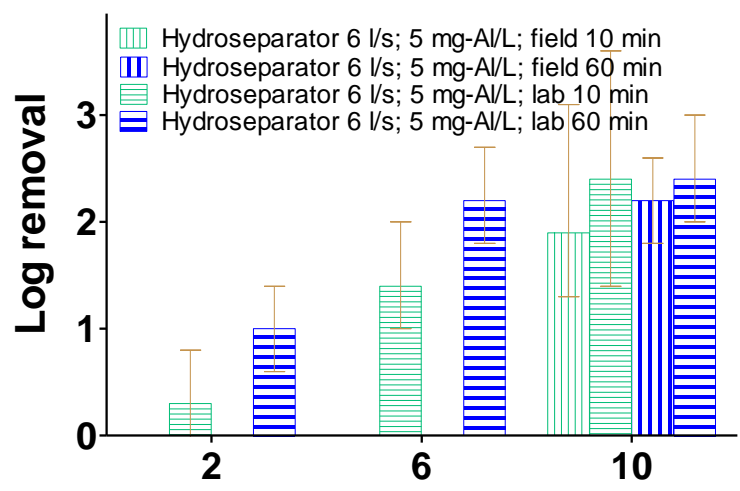

PAA (mg/L)

Figure 4: Removal of Enterococcus from samples treated with different concentration of PAA. T-bars indicate 95\% confidence interval of experimentally observed removal effectiveness

In experiment I, initial sample Enterococcus concentrations were measured as $10^{5.0} \cdot 100 \mathrm{ml}^{-1}$, whilst observed concentrations after disinfection with $10 \mathrm{mg} \cdot \mathrm{L}^{-1} \mathrm{PAA}$ for $60 \mathrm{~min}$ were $10^{1.5-3.7} \cdot 100 \mathrm{ml}^{-1}$, depending on flow rate through the HydroSeparator. PAA disinfection was observed to be more efficient after flow through the HydroSeparator in comparison to samples taken at the inlet and also for lower flow rates of 5-15 l/s. More rapid degradation of PAA in the inlet water (Figure 3) explains the observed lower overall removal of Enterococcus for given PAA doses. This is clearly demonstrated by considering the difference between $\mathrm{AUC}_{60}$ for samples adding $10 \mathrm{mg} \cdot \mathrm{L}^{-1}$ PAA in untreated CSO and which achieved an exposure of $152 \mathrm{mg} \cdot \mathrm{L}^{-1} \cdot \mathrm{min}$, which was about matched by adding $6 \mathrm{mg} \cdot \mathrm{L}^{-1} \mathrm{PAA}$ to HydroSeparator treated water that achieved an exposure of $156-164 \mathrm{mg} \cdot \mathrm{L}^{-1} \cdot \mathrm{min}$.

In experiment III, samples collected following chemical coagulation in the HydroSeparator were disinfected with 3 different concentrations of PAA in the laboratory, to verify observed onsite disinfection efficiency towards Enterococcus. In experiment III, the initial Enterococcus concentration was $10^{4.6} \cdot 100 \mathrm{ml}^{-1}$ and resulting concentration after disinfection with $10 \mathrm{mg} \cdot \mathrm{L}^{-1} \mathrm{PAA}$ for $60 \mathrm{~min}$ observed as $10^{1.9-2.2} \cdot 100 \mathrm{ml}^{-1}$. For field attained disinfection samples, removal of Enterococcus was 1.9 log with 10 min of contact time, whereas observed removal of Enterococcus was 2.4 log when the same PAA concentration was applied in the 
laboratory. Similarly, the removal of Enterococcus was $2.2 \log$ for onsite disinfected samples and $2.4 \log$ for laboratory with a 60 min contact time. Overall removal of Enterococcus was seen to be comparable between laboratory and field-scale disinfection by PAA. Removal of Enterococcus increased when treatment time of PAA increased. When treatment time was increased from $10 \mathrm{~min}$ to $60 \mathrm{~min}$, removal of Enterococcus also increased from $0.3 \log$ to $1.0 \log$ in samples treated with $2 \mathrm{mg} \cdot \mathrm{L}^{-1} \mathrm{PAA}$. Similarly, for application of $6 \mathrm{mg} \cdot \mathrm{L}^{-1}$ PAA, removal of Enterococcus increased from $1.4 \log$ to 2.2 log with increased contact time. The effect of treatment on PAA disinfection efficiency can generally be explained by observed differences in AUC. The observed AUC can clearly be seen to vary, as degradation of PAA is influenced by reaction with particles and organic matter that are removed by chemical coagulation and flow through the HydroSeparator. Overall, it is evident that disinfection efficiency of PAA was more effective in samples subjected to chemical coagulation where suspended solids and dissolved matter were removed, in contrast to non-coagulated samples.

\subsection{Dose dependency of disinfection effectiveness}

In order to determine if the AUC values can be used to predict the disinfection efficiency more accurately than considering nominal concentrations of PAA alone, laboratory disinfection results (a total of 15) with matching concentration profiles of PAA for 60 mins of contact time were considered. Disinfection kinetic models like the Hom's model [32] and the S-model [33] cannot be applied for these data, due to the limited number of disinfection results and contact time tested. The Chick-Watson disinfection kinetics model (equation 3 ) is the first of many suggested equations to predict disinfection kinetics.

$$
\ln \left(\frac{N}{N_{0}}\right)=-\Lambda C t
$$

In eq. 3, $\mathrm{N}$ and $\mathrm{N}_{0}$ are the number of Enterococcus at time $\mathrm{t}$ and the initial number of Enterococcus, respectively, $\Lambda$ is the microbial decay constant, $\mathrm{C}$ is the residual concentration of disinfectant at time $\mathrm{t}$, and $\mathrm{t}$ is the contact time. 
The Chick-Watson disinfection kinetics model is based on the concept that disinfection is proportional to exposure of the organism to the disinfectant. In the current study, it was thus used to compare correlation between disinfection, product of exposure time, and concentration. In figure $5 \mathrm{~A}$, disinfection effectiveness was calculated by calculating $\log _{10}$ of the removal ratio for Enterococcus and plotting against the product of the concentration and exposure time $(\mathrm{C} \cdot \mathrm{t})$. For figure 5B, disinfection effectiveness was calculated as described above for figure $5 \mathrm{~A}$ and plotted against the nominal concentration of PAA $\left(\mathrm{C}_{0}\right)$.

Correlation coefficients for graphs $5 \mathrm{~A}$ and $5 \mathrm{~B}$ were 0.76 and 0.53 , respectively. Thus, reasonable linear correlation for disinfection effectiveness and survival with C.t was observed (figures 5A), while a weak correlation with nominal PAA concentration was observed (figure 5B). Thus, it can be concluded that the inactivation kinetics of Enterococcus can be satisfactorily modelled by the Chick-Watson model for PAA disinfection. 

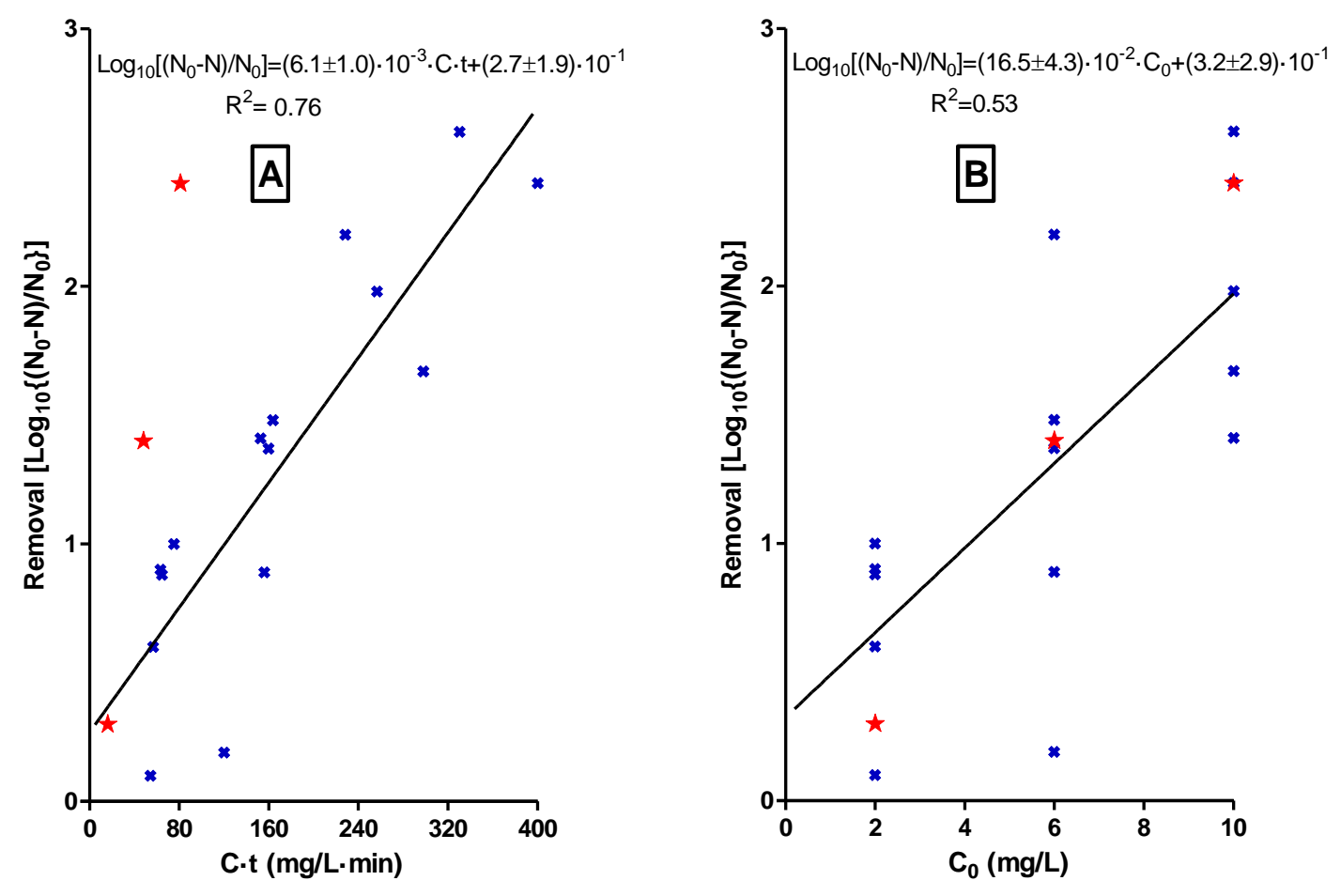

Figure 5: A) Correlation between removal of Enterococcus from PAA treated CSO fractions either exposure (C.t) or removal of Enterococcus vs. nominal dose $\left(\mathrm{C}_{0}\right)$. Data points indicated with a star sign indicate values for 10 min contact time which was not considered for the fitted curves

\subsection{Microbial profile of CSO water}

In the October 2015 CSO event a microbial profile of Enterococcus was made by measuring samples from locations in the CSO structure and the receiving waters before and after CSO events. Based on the flow of CSO water and retention time in the CSO structure, samples were collected for microbial profile, so that the quality of CSO water from the inlet of the Hydroseparator matched when it reached to the receiving water. Furthermore, a sample from the drain well, Kærbyholm canal, Pavebækken, Storå, and Varbjerg Strand was collected prior to the CSO event to obtain information on the pre-existence of Enterococcus (Figure 6).

The initial concentration of Enterococcus was $10^{5.5} \mathrm{MPN}$ per $100 \mathrm{~mL}$ during the CSO event, and was reduced to $10^{3.7}$ MPN per $100 \mathrm{~mL}$ after the disinfection chamber, when treated in the HydroSeparator and disinfected in the disinfection chamber. The number of Enterococcus was almost constant through the constructed 
wetland. In the first receiving surface water called Kærbyholm canal the concentration was almost the same as the effluent of the treatment system, but with dilution into the larger streams of Pavebækken and Storåen the number of Enterococcus will decrease to around the bathing water criteria.

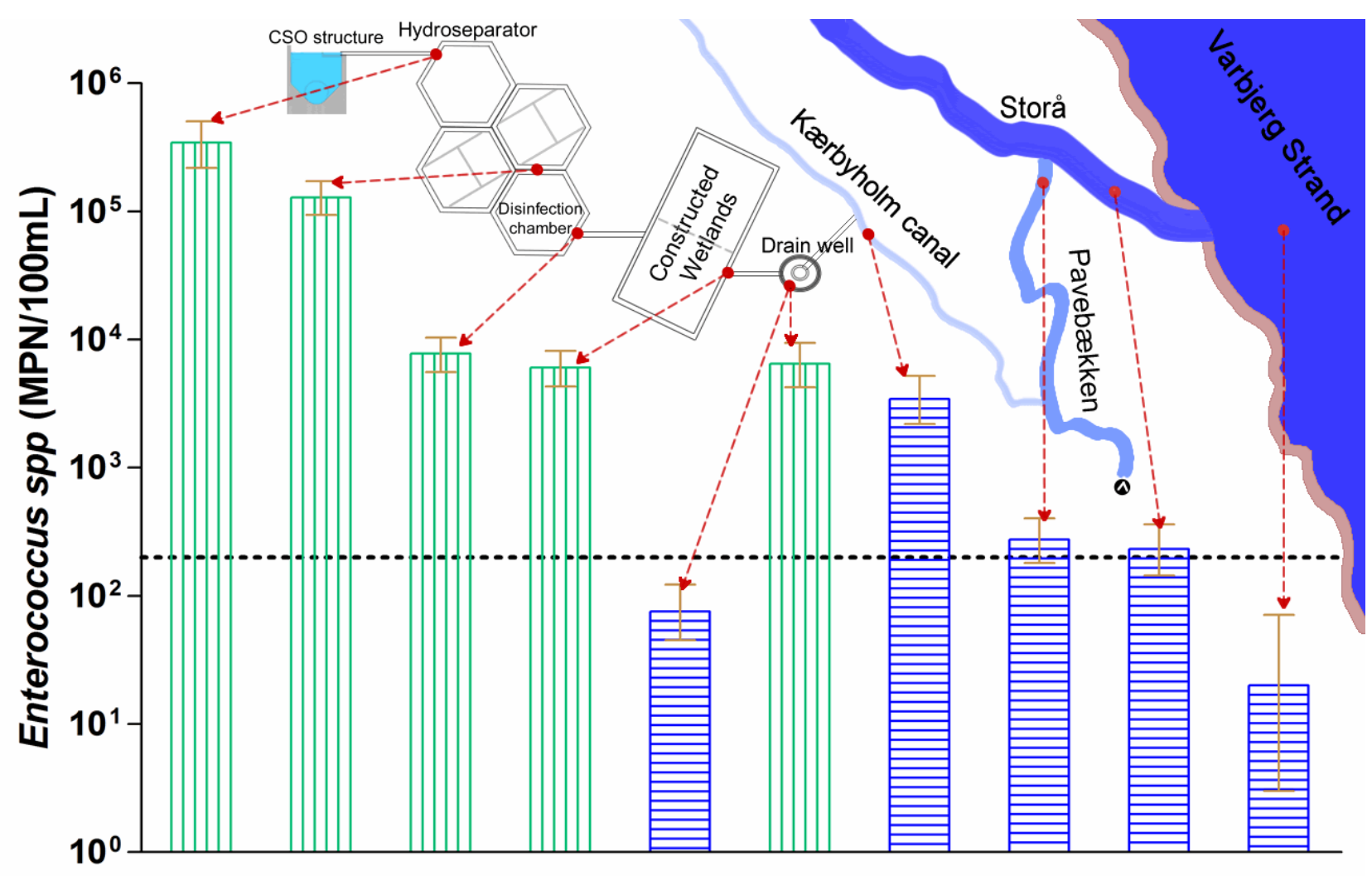

Figure 6: The number of Enterococcus from samples collected at different location of CSO structure and the recipient water. The blue bar with horizontal pattern is the number of Enterococcus in the receiving water prior to the CSO event. T-bars indicate $95 \%$ confidence interval

\section{Conclusion}

Pretreatment of CSO water had a clear effect on disinfection efficiency and overall degradation of PAA. Degradation kinetics of PAA and disinfection efficiency both increased when CSO water was pretreated in the HydroSeparator in combination with induction of chemical coagulation. Besides, this number of indicator bacteria was maintained almost the same as in the recipient when CSO water was discharged after pretreatment and disinfection in the Hydroseparator. 
Furthermore, pretreatment of CSO by coagulation and particle separation impacts on removal of phosphate, suspended solids and a decrease in disinfectant dose should be seen as an additional benefit, since in many cases these parameters are required to meet acceptable overall environmental water quality for effluent.

In summary, a combined treatment of chemical coagulation, particle separation, and disinfection by PAA seems economically and logistically feasible and capable of significantly mitigating negative effects of CSO on receiving surface waters bodies, in terms of both aquatic organism impacts and safe recreational use.

\section{Acknowledgement}

This work is connected to the project "Effektivisering af HydroSeparator til rensning af overløbsvand" funded by the Danish Ministry of the Environment. Ravi K. Chhetri recognized funding for the project through a PhD stipend from DTU. Method development in relation to measurements of bacteria and PAA was made in the recently concluded DesiCSO (http://www.vandibyer.dk/innovationsprojekter/afsluttedeinnovationsprojekter/ip06-desinfektion-af-kloakoverloeb-desicso/) and FRODO (FRODO - Forbedret rensning og desinfektion af overløbsvand, www.vtu-fonden.dk ) projects.

\section{References}

[1] USEPA, Combined Sewer Overflow Technology Fact Sheet Alternative Disinfection Methods, United States Environmental Protection Agency, Washington DC, USA, 1999.

[2] 2006 Directive 2006/7/EC, European bathing water directive. Official Journal of the European Union L64, 37-51, 2006, pp. 37-51.

[3] G. Tchobanoglous, F.L. Burton,, H.D. Stensel, Wastewater Engineering, Treatment and Reuse. Metcalf \& Eddy Inc., 4th ed., McGraw Hill, New York, 2003.

[4] G.C. White, Handbook of chlorination and alternative disinfectants, Vol. Third Edit, 5th ed., John Wiley \& Sons, Inc., New York, 2010.

[5] J. Bayo,, J.M. Angosto,, M.D. Gómez-López, J. Hazard. Mater. 172(1) (2009) 166-71. 10.1016/j.jhazmat.2009.06.157.

[6] S.E. Hrudey,, W.J. Charrois, Disinfection By-products and Human Health, IWA Publishing, London 
United Kingdom, 2012.

[7] C. Nurizzo,, M. Antonelli,, M. Profaizer,, L. Romele, Desalination 176(1-3) (2005) 241-53. 10.1016/j.desal.2004.11.012.

[8] K. Watson,, G. Shaw,, F.D.L. Leusch,, N.L. Knight, Water Res. 46(18) (2012) 6069-83. 10.1016/j.watres.2012.08.026.

[9] G. Svecevicius,, J. Šyvokiene,, P. Stasiunaite,, L. Mickeniene,, J. Syvokiene,, P. Stasiŭnaite, Environ. Sci. Pollut. Res. 12(5) (2005) 302-5. 10.1065/espr2005.04.248.

[10] M. Antonelli,, S. Rossi,, V. Mezzanotte,, C. Nurizzo, Environ. Sci. Technol. 40(15) (2006) 4771-5. 10.1021/es060273f.

[11] D. Falsanisi,, R. Gehr,, D. Santoro,, A. Dell'Erba,, M. Notarnicola,, L. Liberti, Water Qual. Res. J. Canada 41(4) (2006) 398-409.

[12] M. Kitis, Environ. Int. 30(1) (2004) 47-55. 10.1016/S0160-4120(03)00147-8.

[13] J. Koivunen,, H. Heinonen-Tanski, Water Res. 39(18) (2005) 4445-53. 10.1016/j.watres.2005.08.016.

[14] T. Luukkonen,, T. Heyninck,, J. Rämö,, U. Lassi, Water Res. 85 (2015) 275-85. 10.1016/j.watres.2015.08.037.

[15] M.G.C. Baldry, J. Appl. Bacteriol. 54(3) (1983) 417-23.

[16] L. Liberti,, M. Notarnicola, Water Sci. Technol. 40(4-5) (1999) 235-45. 10.1016/S02731223(99)00505-3.

[17] R.K. Chhetri,, D. Thornberg,, J. Berner,, R. Gramstad,, U. Ojstedt,, A.K. Sharma,, H.R. Andersen, Sci. Total Environ. 490 (2014) 1065-72. 10.1016/j.scitotenv.2014.05.079.

[18] R.K. Chhetri,, R. Flagstad,, E.S. Munch,, C. Hørning,, J. Berner,, A. Kolte-Olsen,, D. Thornberg,, H.R. Andersen, Chem. Eng. J. 270 (2015) 133-9. 10.1016/j.cej.2015.01.136.

[19] C. Delporte,, R. Pujol,, P. Vion, Water Sci. Technol. 32(1) (1995) 127-36.

[20] D. Jolis,, M.-L. Ahmad, Water Environ. Res. 76(5) (2004) 474-80. 10.2175/106143004X151563.

[21] V. Plum, Water Sci. Technol. 37(1) (1998) 269-75. 10.1016/S0273-1223(97)00778-6.

[22] A.G. El Samrani,, B.S. Lartiges,, F. Villiéras, Water Res. 42(4-5) (2008) 951-60. 10.1016/j.watres.2007.09.009.

[23] J. Gasperi,, B. Laborie,, V. Rocher, Chem. Eng. J. 211-212(2012) (2012) 293-301. 10.1016/j.cej.2012.09.025.

[24] J. Gasperi,, V. Rocher,, S. Gilbert,, S. Azimi,, G. Chebbo, Water Res. 44(10) (2010) 3065-76. 10.1016/j.watres.2010.02.035.

[25] K. Nielsen,, A. Mørch-Madsen,, P. Mikkelsen,, E. Eriksson, Water 7(3) (2015) 1306-23. 10.3390/w7031306.

[26] N. Johansen,, P. Hallager,, A. Laustsen,, J. Nielsen,, N. Kristensen,, P. Nordemann,, G. Nielsen,, K. Arnbjerg-Nielsen, NOVATECH 2007 - 6th International Conference on Sustainable Techniques and Strategies in Urban Water Management, Lyon, France, 2007,

[27] APHA, Standard Methods for the Examination of water and wastewater (22nd Edition), Vol. 21st Editi, American Public Health Association /American Water Works Association/Water Environment Federation, Washington DC, USA, 2012. 
[28] M. Wagner,, D. Brumelis,, R. Gehr, Water Environ. Res. 74(1) (2002) 33-50.

[29] C.N. Haas,, G.R. Finch, Methodologies for the Determination of Disinfection Effectiveness, American Water Works Association Research Foundation, Denver, Colorado, USA, 2001.

[30] G. Hey,, A. Ledin,, J.L.C. Jansen,, H.R. Andersen, Environ. Technol. 33(9) (2012) 1041-7. 10.1080/09593330.2011.606282.

[31] DesiCSO, Udredning og sammenligning af mulige aktivstoffer for kemisk desinfektion af kloakoverløbsvand. Available at: http://www.vandibyer.dk/31782. Accessed May 6, 2015.

[32] L.W. Hom, Journal of Sanitary Engineering Division Proceeding of the American Socienty of Civill Engineers, 1972, pp. 183-94.

[33] M. Profaizer, Aspetti modellistici e tecniche alternative nella disinfezione di acque potabili: I'acido peracetico. Ph.D. Thesis. Politecnico di Milano, 1998. 